\title{
Sheep responses to grazing ryegrass with AR37 endophyte
}

\author{
L.R. FLETCHER and B.L. SUTHERLAND \\ AgResearch, Lincoln Research Centre, Private Bag 4749, Christchurch 8140, New Zealand \\ lester.fletcher@agresearch.co.nz
}

\begin{abstract}
Over 10 years the health and production of sheep grazing ryegrass with AR37 fungal endophyte was compared to those grazing Standard and AR1 endophytes, and endophyte-free, under four different trial protocols, including short and long term grazing, cultivar effects and seasonal differences. Sheep developed some ryegrass staggers on AR37 treatments but it was less frequent and usually less severe than on Standard. Liveweight gains were similar to those from endophytefree controls, but this could be influenced by the degree of ryegrass staggers. AR37 had no adverse effects on body temperatures, dags or respiration rates. The large agronomic advantages of AR37 outweigh the ryegrass staggers that may occur in sheep, making it a better option in terms of both pasture persistence and animal productivity and welfare than Standard endophyte.
\end{abstract}

Keywords: fungal endophyte, Neotyphodium lolii, perennial ryegrass, Lolium perenne, sheep, liveweight gains, ryegrass staggers

\section{Introduction}

Ryegrass endophytes (Neotyphodium lolii) can have important impacts on the production and persistence of the host ryegrass and the health and production of animals grazing them (Easton 1999; Fletcher et al. 1999).

The development of ryegrasses (Lolium spp.) with the AR1 endophyte eliminated the problem of ryegrass staggers in grazing livestock and greatly improved animal production compared to similar stock grazing the same ryegrass naturally infected with toxic Standard endophyte (Fletcher 2005). However, while AR1 gives protection against some ryegrass pests, such as Argentine stem weevil and pasture mealybug, it does not give the same protection against other insects as Standard endophyte. AR 1 was particularly susceptible to root aphid and gave little protection against black beetle (Popay \& Thom 2009, this volume). AR37 which does not produce ergot alkaloids, lolitrem B and peramine gave exceptional broad spectrum pest protection to its host (Hume et al. 2007). Before these benefits could be captured by the grazing industry the impact of AR37 on grazing animal health and production had to be assessed. This paper reports on responses of hoggets/ lambs grazing ryegrass with AR37, in a number of trials over 10 years.

\section{Materials and Methods}

Four types of grazing trials with different protocols were run from 1999-2009. Although the trials were run separately and at different times within that period their establishment, management and some aspects of the protocols were similar.

\section{Establishment}

The perennial ryegrass (L. perenne) cultivars used in the trials described below were cv. 'Grasslands Nui' and 'GA66', an experimental line related to 'Grasslands Samson'. Unless otherwise specified all ryegrass used, whether infected with AR37 or Standard, or endophyte-free controls were cv. 'Grasslands Nui' when sown before 2001 and 'GA66' post 2001. The viable endophyte content of seed used in these trials was $80 \%$ or greater.

Pure stands of ryegrass were established in a cultivated seed bed following a minimum of a year of cropping. Although the location of trials on the AgResearch Lincoln farm, varied from year to year, the soil type was always Wakanui silt loam. Volunteer species, including legumes, were sprayed out well before grazing. Nitrogen was applied as urea, twice in spring and once each in summer and autumn. Pastures were minimally irrigated ( $40 \mathrm{~mm} /$ application) as part of the normal farm rotation (every 3 weeks in summer, provided soil moistures were not above $50 \%$ of field capacity). When not under trial grazing, pastures were normally managed for maximum covers of $2500 \mathrm{~kg}$ $\mathrm{DM} / \mathrm{ha}$ and minimums of $1000 \mathrm{~kg} \mathrm{DM} / \mathrm{ha}$ with grazing sheep. However, herbage was conserved as baleage in spring of years 2007-2009.

Three trial designs were used from 1999-2009. Sheep were used for all the grazing studies described, because they are the smallest grazing ruminant, which allows for greater animal replication per unit of seed and land available. Coopworth hoggets were used for spring grazings and weaned Coopworth lambs for trials stocked from mid-December onwards.

The four protocols employed were as follows:

\section{Short-term grazing trials}

These compared AR37 with Standard endophyte and either endophyte-free or AR1 endophyte controls in a common cultivar. A bulk of herbage was accumulated 
Table 1 Effect of endophyte on liveweight change and ryegrass staggers score in lambs grazing trials since 1999, for which maximum mean ryegrass staggers score on AR37 exceeded or did not exceed 2.0.

\begin{tabular}{|c|c|c|c|c|c|c|}
\hline \multirow[b]{3}{*}{ Year } & & & \multicolumn{4}{|c|}{ Endophyte } \\
\hline & \multicolumn{2}{|c|}{ Endophyte-free } & \multicolumn{2}{|c|}{ Standard } & \multicolumn{2}{|c|}{ AR37 } \\
\hline & $\mathrm{LWG}^{1}$ & $\mathrm{RGS}^{2}$ & LWG & RGS & LWG & RGS \\
\hline \multicolumn{7}{|c|}{ Maximum mean ryegrass staggers score on AR37 was $\geq 2.0$} \\
\hline 1999 & $134^{a}$ & 0 & $34^{\mathrm{b}}$ & $2.3^{\mathrm{A}}$ & $62^{\mathrm{b}}$ & $2.1^{\mathrm{A}}$ \\
\hline 2000 & $14^{\mathrm{a}}$ & 0 & $-64^{b}$ & $3.3^{\mathrm{A}}$ & $-12^{\mathrm{a}}$ & $2.0^{\mathrm{B}}$ \\
\hline 2002 & $62^{\mathrm{a}}$ & 0 & $-38^{b}$ & $3.4^{\mathrm{A}}$ & $31^{\mathrm{a}}$ & $2.0^{\mathrm{B}}$ \\
\hline 2004 & $81^{\mathrm{a}}$ & 0 & N/A & $3.8^{\mathrm{A}}$ & $58^{a}$ & $3.8^{\mathrm{A}}$ \\
\hline 2006 & $132^{\mathrm{a}}$ & 0 & N/A & $3.8^{\mathrm{A}}$ & $137^{\mathrm{a}}$ & $2.3^{\mathrm{B}}$ \\
\hline \multicolumn{7}{|c|}{ Maximum mean ryegrass staggers score on AR37 did not exceed 2.0} \\
\hline 2001 & $91^{\mathrm{a}}$ & 0 & $75^{\mathrm{a}}$ & $2.6^{\mathrm{A}}$ & $102^{\mathrm{a}}$ & $0.7^{\mathrm{B}}$ \\
\hline 2002 & $79^{\mathrm{a}}$ & 0 & $64^{\mathrm{a}}$ & $2.4^{\mathrm{A}}$ & $70^{\mathrm{a}}$ & $1.3^{\mathrm{B}}$ \\
\hline 2003 & $191^{\mathrm{a}}$ & 0 & $142^{\mathrm{b}}$ & $3.0^{\mathrm{A}}$ & $202^{\mathrm{a}}$ & $0.0^{\mathrm{B}}$ \\
\hline 2006 & $128^{\mathrm{a}}$ & 0 & N/A & $4.8^{\mathrm{A}}$ & $133^{a}$ & $0.9^{\mathrm{B}}$ \\
\hline 2007 & $106^{a}$ & 0 & $61^{b}$ & $2.0^{\mathrm{A}}$ & $131^{a}$ & $0.0^{\mathrm{B}}$ \\
\hline 2008 & $157^{a}$ & 0 & $\mathrm{~N} / \mathrm{A}$ & $3.0^{\mathrm{A}}$ & $224^{\mathrm{b}}$ & $1.4^{\mathrm{B}}$ \\
\hline 2009 & $104^{a}$ & 0 & $\mathrm{~N} / \mathrm{A}$ & $2.6^{A}$ & $145^{\mathrm{a}}$ & $1.0^{\mathrm{B}}$ \\
\hline
\end{tabular}

Means within the same row with different superscripts ( ${ }^{a b c}$ for $\left.L W G\right)$ and (ABC for RGS) differ significantly $(P<0.05)$. N/A - no data because of severe staggers within 2 weeks of trial start and removal of all lambs for ethical reasons. ${ }^{1} \mathrm{LWG}$ - Lamb growth rate g/hd/ day; ${ }^{2}$ RGS - Maximum ryegrass staggers score (0-5) scale.

then grazed by a minimum of ten hoggets, or weaned lambs, per paddock in spring and summer and/or autumn, respectively, for a minimum of 28 days. In summer and autumn lambs were introduced onto pastures which were potentially close to maximum toxicity (based on previous experience), especially for the tremorgens of lolitrem B in Standard and epoxy-janthitrems, the likely tremorgens in AR37 (Tapper \& Lane 2004). As a consequence, serious ryegrass staggers often developed rapidly, particularly on Standard.

\section{Cultivar comparisons}

Short-term grazing trials, as above, compared four different ryegrass cultivars infected with AR37, with 'GA66'AR37 as the control. The different cultivars were not all evaluated in the same year, but 'GA66' AR37 was common to all years. The trials (28-42 days) were managed to create the worst case scenario for potential toxic responses in hoggets/lambs. As a consequence, herbage quality was often compromised in summer and autumn. This resulted in less than optimum animal growth rates during the summer/autumn.

\section{Seasonal growth rates}

A one year grazing trial where all the herbage grown that year was grazed by trial hoggets or lambs between cover limits of $2500-1000 \mathrm{~kg} \mathrm{DM} / \mathrm{ha}$. Hoggets or lambs were set-stocked on replicated (x 3) paddocks of each treatment. There were a minimum of eight trial sheep per paddock but similar mean herbage on offer per head was maintained by adding or subtracting "unmeasured grazer sheep". If covers dropped below $1000 \mathrm{~kg} \mathrm{DM} /$ ha on any one treatment all sheep were removed to a common endophyte-free pasture until trial pastures had regrown. While grazing days were recorded for each treatment the data are not presented here.

\section{Ryegrass staggers monitoring trial}

The 2 year trial was designed to compare the seasonal pattern of ryegrass staggers between hoggets/lambs grazing AR37 and Standard treatments under the same environmental conditions and management. Ten hoggets/lambs grazed endophyte-free, Standard endophyte and AR37 treatments from early October until ryegrass staggers became so severe that the trial had to be terminated for ethical reasons. Although the ryegrass staggers seen in AR37, is not caused by lolitrem B, as is the case for Standard, the symptoms at all stages were indistinguishable from those seen on Standard. 
Table 2 Effect of ryegrass cultivar on responses of lambs grazing ryegrass infected with AR37 endophyte. Control = 'GA66'.

\begin{tabular}{cccc}
\hline & Cultivar & $\begin{array}{c}\text { Lamb growth } \\
\text { rate } \\
\text { g/hd/day }\end{array}$ & $\begin{array}{c}\text { Mean ryegrass } \\
\text { staggers } \\
\text { score }(0-5)\end{array}$ \\
Year 1 & Control & $135^{\mathrm{a}}$ & $0.8^{\mathrm{a}}$ \\
Year 2 & A & $77^{\mathrm{b}}$ & $0.5^{\mathrm{a}}$ \\
& & $91^{\mathrm{b}}$ & $0.5^{\mathrm{a}}$ \\
& Control & $133^{\mathrm{a}}$ & 0 \\
Year 3 & $123^{\mathrm{a}}$ & 0 \\
& & & \\
& Control & $145^{\mathrm{a}}$ & $1.0^{\mathrm{a}}$ \\
& D & $85^{\mathrm{b}}$ & $1.7^{\mathrm{b}}$ \\
& & $99^{\mathrm{b}}$ & $1.0^{\mathrm{a}}$ \\
\hline
\end{tabular}

Means within the same column with different superscripts differ significantly $(\mathrm{P}<0.05)$.

\section{Measurements}

Measurements for protocols 1, 2 and 3 included the following:

\section{Herbage}

Herbage mass was determined using an electronic pasture meter to confirm that all treatments and control paddocks in protocols 1 and 2 had similar herbage mass (covers) at the start of grazing. The same technique was used to monitor herbage mass for protocol 3 and make appropriate adjustments to stocking rates.

Frequency of endophyte infection in ryegrass was determined on 50 tillers collected at random from each replicate paddock and assayed using immunoblot (Hahn et al. 2003). As noted above, endophyte infection frequencies were never below $80 \%$.

\section{Animal}

Hogget/lamb liveweights were recorded at the beginning and end of the trial and at the mid-point.

Ryegrass staggers was scored in individual animals every 5 days using a 0 to 5 Keogh scale (Keogh 1973).

Rectal temperatures and respiration rates were measured at least once, on all hoggets/lambs after a minimum of 14 days grazing on treatments. To impose sufficient heat load on the animals, measurements were recorded after they had been housed in a modified tunnel house for 4 hours, with an ambient temperature between 35 and $40^{\circ} \mathrm{C}$ (Fletcher 1993).
Table 3 Seasonal effect of endophyte on liveweight gain (g/hd/day) in lambs/hoggets grazing cv. 'GA66' ryegrass.

\begin{tabular}{lcccc}
\hline & & \multicolumn{3}{c}{ Endophyte } \\
\cline { 3 - 5 } Season & Endophyte-free & Standard & AR1 & AR37 \\
\hline Summer & $78^{\mathrm{b}}$ & N/A & $126^{\mathrm{a}}$ & $120^{\mathrm{a}}$ \\
Autumn & $56^{\mathrm{a}}$ & $29^{\mathrm{a}}$ & $23^{\mathrm{a}}$ & $67^{\mathrm{a}}$ \\
Winter & $250^{\mathrm{a}}$ & $193^{\mathrm{b}}$ & $261^{\mathrm{a}}$ & $250^{\mathrm{a}}$ \\
Spring & $181^{\mathrm{a}}$ & $173^{\mathrm{a}}$ & $187^{\mathrm{a}}$ & $178^{\mathrm{a}}$ \\
\hline
\end{tabular}

Means within the same row with different superscripts differ significantly $(\mathrm{P}<0.05)$. N/A - see Table 1.

Dag scores on each animal (0-5 scale) were recorded for the first 4 years of these studies (Fletcher 1993). From 2002 onwards, sheep were all crutched immediately before going onto the trials, to minimise the risk of flystrike.

Measurements for protocol 4 were restricted to liveweight at the beginning and end of trial and ryegrass staggers scores every 5 days after the first signs of staggers were noted.

\section{Statistical analysis}

All statistical analysis was done by ANOVA within GenStat v 11.1, using individual treatment mobs as the statistical unit.

\section{Results}

\section{Short term grazing trials}

In summer and autumn of all years lambs grazing ryegrass with Standard endophyte, had consistently higher mean respiration rates and rectal temperatures when subjected to heat stress, compared to those grazing endophyte-free and AR37 treatments $(\mathrm{P}<0.05)$. Mean rectal temperatures $\left({ }^{\circ} \mathrm{C}\right)$ were 40.5 (40.2 to 41.0 ), 40.4 (40.2 to 40.7) and 40.7 (40.3 to 41.2) for AR37, endophyte-free and Standard, respectively. In the same order, respiration rates (breaths/minute) were 94 (83 to 109), 85 (79 to 103) and 105 (90 to 119). Ranges for both parameters are in brackets. This, in conjunction with ryegrass staggers occurring in all years on Standard endophyte treatments but not on endophyte-free, confirmed that conditions were conducive to expression of ryegrass endophyte toxicoses in all years.

Hogget growth rates in spring (first 4 years) were not significantly different between those grazing ryegrass with Standard endophyte, AR37 endophyte or endophyte-free, and averaged $145 \mathrm{~g} / \mathrm{hd} /$ day. There were no signs of ryegrass staggers in hoggets grazing any of the treatments in spring of any year.

Summer and autumn growth rates for these 
Figure 1 Difference in seasonal pattern of ryegrass staggers scores (0-5 ascending scale) between years in lambs grazing ryegrass infected with Standard or AR37 endophyte.

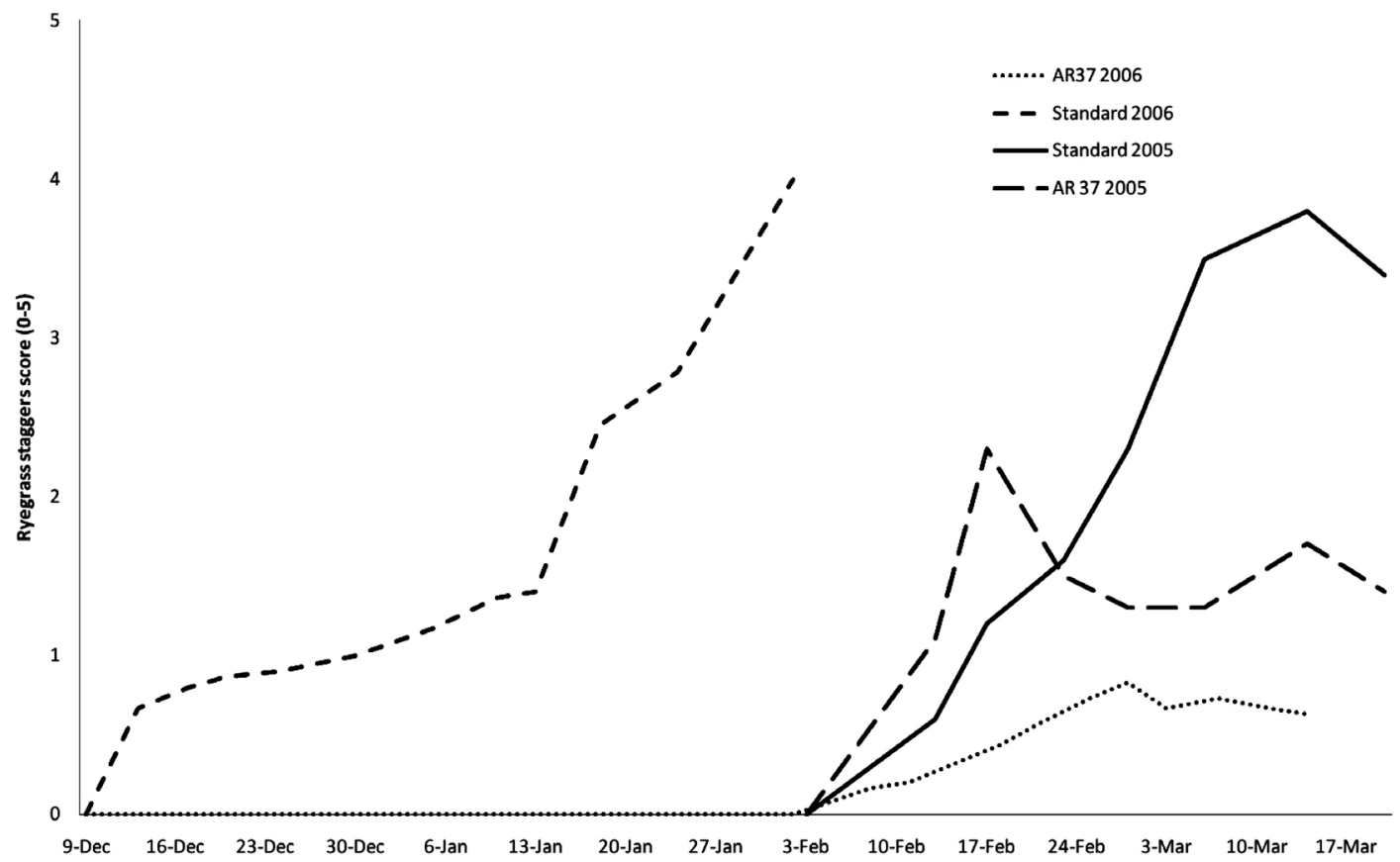

treatments, in short-term grazing trials, are divided into two sections (Table 1):

a Mean growth rates and ryegrass staggers scores in years when peak ryegrass staggers score in lambs on AR37 was greater than or equal to 2 .

b Mean growth rates and ryegrass staggers scores in years when peak ryegrass staggers on AR37 treatments was less than score of 2 .

With one exception in 2006 growth rates on AR37 treatments were lower than on endophyte-free treatments when maximum mean ryegrass staggers scores were 2 or greater while they were on the trial, although this difference was only significant in 1999. Conversely, when the maximum mean ryegrass staggers score was less than 2, growth rates of lambs grazing AR37 treatments were equal to or higher than those on endophyte-free treatments.

Growth rates of lambs grazing either the endophytefree or AR37 treatments were higher than for those grazing Standard treatments, regardless of peak mean ryegrass staggers score for AR37 lambs, the differences reaching significance in over half the years.

Ryegrass staggers varied from year to year, but the maximum mean ryegrass staggers score for AR37 was similar $(\mathrm{P}>0.05)$ to those on Standard on only two occasions. In other years it was generally about half as severe on AR37 treatments as on Standard (Table 1).

\section{Cultivar comparisons}

Lamb growth rates were significantly affected by the host ryegrass cultivar (Table 2). Growth rates of lambs grazing the AR37 control ('GA66') were consistent over the 3 years, but lambs grazing cultivars A, B, D and $\mathrm{E}$ all had significantly lower growth rates. There was no evidence of cultivar/endophyte interaction in these differences.

\section{Seasonal growth rates}

Lamb growth rates in summer during the 12 month grazing trial (protocol 3) reached a similar maximum for those grazing AR1 and AR37 (P>0.05) that was significantly higher than those on endophyte-free $(\mathrm{P}<0.05)$. Growth rates on Standard were not measured, because serious ryegrass staggers led to animal removal before sufficient grazing time had elapsed to get meaningful growth rates.

Autumn growth rates on the 12 month trial were low. They were highest on AR37, but there was no significant difference between any of the treatments. In winter on the same trial, there was no difference in growth rates between lambs grazing AR1, AR37 and endophyte-free, but all were significantly better than 
those on Standard $(\mathrm{P}<0.05)$. There was no difference in lamb growth rates between any of the treatments in spring which is consistent with short-term grazing trial results. Mean rectal temperature and respiration rates of lambs grazing AR37 treatments were similar to those for protocol 1 .

\section{Ryegrass staggers monitoring trial}

Although the ryegrass staggers seen in AR37 is not caused by the toxin lolitrem B (produced by Standard endophyte), the signs at all stages were indistinguishable from those seen on Standard. However, protocol 3 showed the time of onset, severity and duration of staggers (while still on pastures) can vary considerably (Fig. 1).

In 2005, ryegrass staggers developed first in lambs grazing AR37 treatments rapidly rising to a peak mean score of 2 to 3 in February, then dropping rapidly to level off at 1.3 to 1.7 in March. Mean scores of the lambs grazing Standard treatments over the same period also rose rapidly from the beginning of February peaking in early March at 3.8. In 2006, signs of ryegrass staggers became evident in Standard treatments early in December and increased in incidence and severity to a maximum at a mean score of 4 in late January. All animals were so badly affected they were removed from the trial. Under the same conditions and management lambs grazing AR37 were free of ryegrass staggers until early February increasing slowly to peak at a mean score of 0.8 by late February.

Mean dag scores for lambs grazing AR37 were similar to those on endophyte-free $(0.45)$ but half those of lambs grazing Standard endophyte $(0.9)(\mathrm{P}<0.05)$.

\section{Discussion}

It should be noted that many of the studies described in this paper were designed to create the worst case scenario for toxicity on Standard endophyte pastures, not to optimise animal growth rates. As a consequence there was significant year to year variation in lamb growth rates on all treatments. However, growth rates of lambs grazing AR37 treatments were generally not significantly different to those grazing endophyte-free ryegrass or ryegrass with AR1, and were superior those grazing ryegrass infected with Standard endophyte. There was a tendency for growth rates to be suppressed for animals grazing AR37 pasture when mean ryegrass staggers scores were greater than or equal to 2 . This is understandable because a mean score of 2 is likely to include a number of lambs with serious staggers ( $>$ 4), which would directly impair their ability to graze, thus increasing growth rate variability within flocks and reducing mean growth rate.

The difference in growth rates between cultivars infected with AR37 does not appear to be a result of interaction between the cultivar and the endophyte, but rather a difference in the herbage quality of the cultivars per se.

Voluntary tightening of ethical standards relating to ryegrass staggers for the later trials meant that animals were removed from treatments at an earlier stage (lower score) of ryegrass staggers than had been the case before 2008 .

These studies show that ryegrass with AR37 can cause ryegrass staggers, the symptoms of which are indistinguishable from those caused by lolitrem B produced by Standard endophyte. Like the ryegrass staggers caused by lolitrem B, the incidence, severity and time of onset varied considerably from year to year. Whether environmental conditions conducive to ryegrass staggers with AR37 are the same as those exacerbating staggers with Standard endophyte is still unclear. While there has not been definitive verification, it is likely that AR37 staggers are caused by a group of alkaloids designated epoxy-janthitrems (Tapper \& Lane 2004) which have some similarities in structure to lolitrem B.

Since ryegrass with AR37 does not produce ergot alkaloids it is not surprising that body temperatures, respiration rates and dags in lambs grazing these pastures are similar to those grazing endophyte-free ryegrass. This is backed up by similar serum prolactin levels measured in lambs grazing ryegrass without endophyte or with AR37 in the first 3 years of these studies (data not presented). The results reported here are consistent with those previously reported (Fletcher 2005).

These studies cover only one soil type and environment with a monoculture of ryegrass. Continuing them over 10 years, did introduce some climatic variation. Extrapolating from these studies to various farm types and environments throughout New Zealand, as with any grazing study, should include the potential for some variation in animal response. Caution should also be exercised when extrapolating these results to cattle, deer, horses and other animal species.

Our results indicate that growth rates of hoggets and lambs on AR37 pastures are likely to be similar to those on endophyte-free ryegrass or AR1, provided there isn't a severe outbreak of ryegrass staggers. Further, the incidence and severity of ryegrass staggers on AR37 is generally much lower than that of lambs grazing Standard pasture. These results coupled with the exceptional agronomic advantages of AR37 ryegrass (Hume et al . 2007) make it a better option than Standard in any environment, with significant advantages in terms of livestock productivity and animal welfare. Its agronomic robustness will be superior to that of AR1, especially in northern regions with high black beetle challenge. 


\section{Conclusions}

In the absence of ryegrass staggers, growth rates of lambs grazing ryegrass with AR37 are similar to those grazing endophyte-free ryegrass, and superior to those grazing ryegrass with Standard endophyte. AR37 can cause ryegrass staggers but averaged over 10 years, the incidence and severity is only half that of comparable Standard pastures. There were no other adverse responses to grazing ryegrass with AR37.

On this basis there can be no justification for returning to ryegrass with Standard endophyte, even where there is dissatisfaction with the persistence of other ryegrass/ endophyte associations.

\section{ACKNOWLEDGEMENTS}

FoRST, M\&WNZ and PGG Wrightson Seeds for funding. Dr's David Baird and David Saville for help with statistical analysis. Carol Fletcher for technical assistance and data recording.

\section{REFERENCES}

Easton, H.S. 1999. Endophyte in New Zealand ryegrass pastures, an overview. Ryegrass endophyte: an essential New Zealand symbiosis. Grassland Research and Practice Series 7: 1-9.

Fletcher, L.R. 1993. Grazing ryegrass/endophyte associations and their effect on animal health and performance Proceedings of the Second International Symposium on Acremonium/Grass Interactions. Plenary Papers: 115-120.
Fletcher, L.R. 2005. Managing ryegrass-endophyte toxicoses. pp. 229-241. In: Neotyphodium in coolseason grasses. Eds. Roberts, C.A.; West, C.P.; Spiers, D.E. Blackwell, Ames, IA.

Fletcher, L.R.; Sutherland, B.L.; Fletcher, C.G. 1999. The impact of endophyte on the health and productivity of sheep grazing ryegrass-based pastures. Ryegrass endophyte: an essential New Zealand symbiosis. Grassland Research and Practice Series 7: 11-17.

Hahn, H.; Huth, W.; Schoberlein, W.; Diepenbrock, W. 2003. Detection of the endophytic fungi in Festuca spp. by means of tissue print immunoassay. Plant Breeding 122: 217-222.

Hume, D.E.; Ryan, D.L.; Cooper, B.M.; Popay, A.J. 2007. Agronomic performance of AR37-infected ryegrass in northern New Zealand. Proceedings of the New Zealand Grassland Association 69: 201-205.

Keogh, R.G. 1973. Induction and prevention of ryegrass staggers in grazing sheep. New Zealand Journal of Experimental Agriculture 1: 55-57.

Popay, A.J.; Thom, E.R. 2009. Endophyte effects on major insect pests in Waikato dairy pasture. Proceedings of the New Zealand Grassland Association 71: 121-126.

Tapper, B.A.; Lane, G.A. 2004. Janthitrems found in a Neotyphodium endophyte of perennial ryegrass. Proceedings of the 5th International Symposium Neotyphodium/Grass Interactions: 301-302. 